\title{
The Correlation The Internet Addiction Toward Teenagers Religiosity and Intelligence Quotient In Banjarmasin City
}

\author{
Imadduddin ${ }^{1}$, Yulia Hairina ${ }^{2}$ \\ Universitas Islam Negeri Antasari Banjarmasin \\ Email : ${ }^{1}$ imadduddin@uin-antasari.ac.id, ${ }^{2}$ yhairina@uin-antasari.ac.id
}

\begin{abstract}
The internet has become a primary need for everyone nowasdays, including teenagers. Ease access to information through the internet is one of factors that make teenagers addicted to the internet. The self-control factor is an important factor that is often associated with internet addiction, besides that internet addiction is also thought to be caused by a lack of internalization of religious values or what is called religiosity and Intelligence Quotient. The research method in this study was field research by using descriptive and correlational quantitative approaches. The research subjects in this study were teenagers 14 to 24 years who lived in Banjarmasin city with totaling 712. The composition was 324 males and 388 females. The sampling technique used in this study was the Proportionate Stratified Random Sampling procedure, namely the sample selection process, where all members of the population had the same opportunity to be selected by considering the strata (levels). Based on the results of the study, it was found that the Sig-value was $0.972(\mathrm{P}>0.05)$. So, It could be concluded that internet addiction had no significant correlation to teenagers' religiosity and Intelligence Quotient in Banjarmasin City.
\end{abstract}

Keywords: Internet Addiction, Religiosity, Intelligence quotient

\begin{tabular}{|c|c|c|c|c|}
\hline Submission & Review Process & Revised & Accepted & Published \\
\hline November 23, 2020 & $\begin{array}{c}\text { April 14, 2021 - } \\
\text { May 20, 2021 }\end{array}$ & June 6, 2021 & June 7, 2021 & June 30, 2021 \\
\hline
\end{tabular}

\section{Introduction}

In line with the development of Information and Communication Technology in the current era of the Industrial revolution 4.0. It is very influential on the lifestyle of individuals. One of the fastest growing technological developments is the internet. The presence of the internet has made the world borderless and narrower. The internet helps individuals to communicate or find things they need or information they need without going to the place. It is even undeniable that the internet has become a primary need for most people (Saniatuzzulfa \& Wijiyanti, 2019), the internet has also been used by people of various ages and generations, especially teenagers. Adolescents have a high dependence on searching for information on the internet (J. Kurniawati \& Baroroh, 2016)
The Data from APJII (Association of Indonesian Internet Service Providers) explained that in 2018, based on survey results and polls, internet users in Indonesia increased by 27.91 million $(10.12 \%)$ to 171.18 million people. It meant that internet user penetration in the country has increased $64.8 \%$ of the total population of 264.16 million people and $64 \%$ was teenagers.

APJII recorded that the highest penetration came from the age of 15-19 years at $91 \%$. Followed by the age group of $20-24$ years $(88.5 \%)$ and $25-29$ years $(82.7 \%)$. The lowest penetration came from the group of 65 years and over at $8.5 \%$. The results of another survey conducted by Yahoo and Taylor Nelson Sofres (TNS) Indonesia, it showed that internet users were dominated by teenagers aged 15-19 years, the second rank was aged 20-24 years and the last rank is 45-50 years old. According 
to a News Sky report, most of them used the internet to play social media. The data above showed that teenagers or today's generation used the internet a lot.

The internet is like a double-edged sword. Internet usage by teenagers can make a positive and negative impact, this happens because teenagers tend to be easily influenced by the social environment without considering the effect of which will be received when doing internet activity (Ekasari \& Darmawan, 2012) On the positive side of this technology could be useful if it is used for good and useful things, such as looking for school learning materials, discussion materials, looking for scholarship programs, consulting with experts, distance learning, looking for multimediabased teaching methods and so on. But on the other hand, the use of the internet can shift to negative things and this must be the concern of the whole community.

The ease of access to information through the internet is one of the factors that make many teenagers addicted to the internet. This addiction is indicated by several criteria as follows: feeling happy when it is online and it is not happy when it is offline. Attention is only focused on the internet, increased usage, unable to regulate internet use, dares to lose because of the internet, and uses the internet as a way to escape from problems (KS Young, 1996). Internet use may be beneficial when it is at a normal level, but high levels of internet use can interfere with daily life such as psycho-social decline, relationships and neglect of academic and work responsibilities (Koc, 2011).

The results of the study concluded that one of the internal factors in individuals that forms addiction was self-control. Selfcontrol factor was an important factor that was often associated with problematic internet use. For example, in a study conducted by Annisa Kurniawati (A. Kurniawati, 2017) showed that the effect of self-control on internet addiction was $8.4 \%$. The same research was also conducted in Surakarta by Anang Ariyanto (Ariyanto, 2017) in which self-control contributed $23.6 \%$ effectively. In addition, another study conducted by Muna et al (Muna \& Tri Puji, 2014) "The relationship between self-control and the tendency of social media addiction in adolescents" resulted in an effective contribution of $15.1 \%$. Self-control ability was negatively related to internet addiction. It was stated that the higher the selfcontrol, the lower the internet addiction and vice versa. Individuals who had high selfcontrol were able to change events and become the main agent in directing and regulating behavior that leads to positive consequences.

In addition, internet addiction is thought to be caused by the lack of internalization of religious values in the daily lives of teenagers. Moreover, according to Elisabeth (Hurlock, 2000), at the age of adolescence, the level of interest in religion is relatively low, due to the expansion of their social network, and interacting with various groups and different cultural and religious backgrounds. According to Erick Fromm, an individual, including teenagers, will not be easily affected by the negative impacts of a change that occurs in their environment, if the individual gets an introduction and deepening of religiosity.

This is because religion can reduce a person's tendency to violate norms. Religion can help a person to have a moral sense and religion becomes a guide in life. Religious life in individuals can be seen at the level of religiosity, and religiosity can affect individual behavior (Jalaluddin, 2008). Among the behaviors that are influenced by religiosity is the behavior of adolescents in using the internet. Individuals with a high level of religiosity are those who have a personality that is closely tied to the religion they believe in. 
The researchers assumed that the actor of religiosity was an important factor in a teenager to overcome internet addiction behavior, especially accessing things that are negative. Understanding of religious teachings had a function as a means of controlling human attitudes and behavior so that they remained in line with prevailing cultural values. The moral teachings of religion were used as the main guide for its adherents to control attitudes. If the moral teachings of religion were well embedded in adolescents, they would control and refrain from excessive internet access behavior. This was reinforced by research conducted by Basri (2014) which concluded that religiosity could influence and contribute to the level of internet addiction in college students.

In addition, one of the factors thought to be associated with internet addiction in adolescents was Intelligence Quotient. Intelligence Quotient was defined as the ability to think logically to find objective, accurate facts, and to predict risks, see the consequences of any decisions that exist (Putri, 2016).

The existence of Intelligence Quotient possessed by individuals would be able to use the internet according to their needs and not forget their main duties as a teenager who is in school. On the other hand, low Intelligence Quotient caused teenagers to disable to use the internet

properly. Good intellectual that the individual would result in a conclusion and commitment to say no to unhealthy Internet use (Nahak et al., 2019).

Considering this background, the researchers were interested in examining the level of teenagers' internet addiction in Banjarmasin City and its correlation to the teenagers' religiosity and the Intelligence Quotient in Banjarmasin City.

\section{Research Methods}

The type of research used in this research was field research using descriptive and correlational quantitative approaches. The sample in this study were male and female adolescents aged 14-24 years and living in the city of Banjarmasin.

The city of Banjarmasin consists of 5 sub-districts, there are the Central Banjarmasin, South Banjarmasin, Northern Banjarmasin, East Banjarmasin, and West Banjarmasin. While the object was reliugistas (X1), Intellectual Intelligence (X2), and Addictions Internet (Y). Based on data from the Central Statistics Agency (BPS) of South Kalimantan Province, the total population (population) 14-24 years old was 677 .

In order to obtain a sample that could describe the population, in determining the sample of this study, a formula based on the Proportion or Isaac and Michael formula with an error rate of $5 \%$ was used.

The sampling technique used in this study was the Proportionate Stratified Random Sampling procedure, which was a sample selection process where all members of the population have the same opportunity to be selected by considering the strata (levels) that exist in the population. The sampling criteria used in this study were 14-24 years old, male and female and domiciled in Banjarmasin city.

In this study, the research paradigm that would be used uses a dual paradigm with one dependent variable (bound) and two independent variables (free). The research paradigm could be seen in Chart 1 below:

Chart 1

Research paradigm

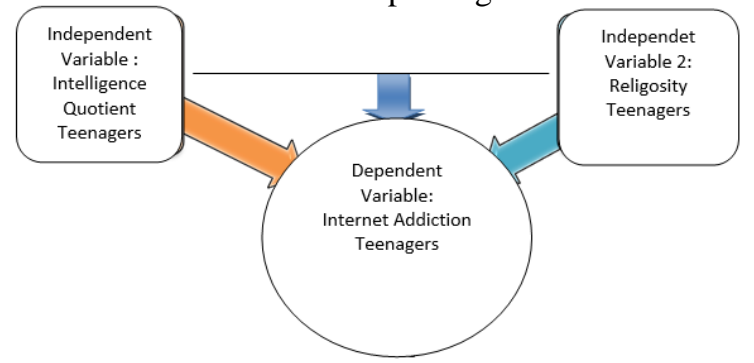


In order to obtain the desired data, the research instrument used the Internet Addiction Test (Internet Addiction Test ) developed by Young (2016) with Cronbach's alpha reliability of 0.895 (Prasojo et al., 2018), the Religious Scale that developed by the author of the theory of the rally giusitas Glock \& Stark (1994) with reliability Cronbach's alpha 0.842 and CFIT ( Culture Fair Intelligence Test ) developed by Cattel with reliability Cronbach's alpha 0.683 (Kumara, 1989) statistical method used to test the hypothesis of linear regression multiple. In this study, the tool used for data analysis is SPSS 24.

\section{Results and Discussion}

\section{Research Subject Profile}

The subjects in this study were adolescents aged 14 to 24 years and domiciled in the city of Banjarmasin. Complete data related to the profile of research subjects could be seen in the following table:

Table 1.

Research Subject Profile

\begin{tabular}{clcc}
\hline No & Criteria & Amount & Percentage \\
\hline 1 & $\begin{array}{l}\text { Number } \\
\text { of } \\
\text { Subjects }\end{array}$ & & \\
\hline & $\mathrm{N}$ & 712 & \\
\hline 2 & Gender & & \\
\hline & Man & 324 & 45.51 \\
\hline girl & 388 & 54.49 \\
\hline 3 & Age & & \\
\hline & 14 & 100 & 14.04 \\
\hline & 15 & 165 & 65.31 \\
\hline & 16 & 113 & 15.87 \\
\hline & 17 & 17 & 4.35 \\
\hline
\end{tabular}

\section{Descriptive Analysis level of religiosity Teenagers}

By comparing each score obtained by the subject with the norm made by the researcher, the descriptive data on the level of religiosity was obtained as followed:
Table 2

The Category of Youth Religiosity Level

\begin{tabular}{lll}
\hline Category & Amount & Percentage \\
\hline Low & 1 & 0.14 \\
\hline Medium & 61 & 8.57 \\
\hline High & 650 & 91 \\
\hline
\end{tabular}

From table 2, it could be seen that the level of teenagers' religiosity in Banjarmasin city was in the low category of 1 person or $0.14 \%$ which was then 61 or $8.57 \%$, for the medium category and 650 people or $91 \%$ which was high. From this explanation, it could be concluded that the level of teenagers' religiosity in Banjarmasin city was mostly in the high category.

This meant that the internalization of religious values in Banjarmasin could be concluded well, internalization here was related to belief in Islamic religious teachings, especially both in the heart and in speech. The high the religiosity of teenagers would be more obedient to carry out all His commands and stay away from all that is prohibited and the daily behavior carried out reflects the teachings of his religion.

The high level of religiosity possessed by the majority of adolescents in Banjarmasin City was possible because teenagers gain knowledge and inculcate religious teachings from schools in teaching and learning activities and outside teaching and learning activities so that it affected the religious level of the majority of teenagers. On the other hand, the research was done by Suhardin \& Hayadin (2017) stated that the level of religious teenagers was more dominant was personal, it has not just had intervention from the school but also religiosity influenced by intervenes on the background of the family, as well as related social background culture where teenagers lived.

Regarding the socio-cultural background, the Banjar people with their culture had a dominant element of religiosity that was identical to Islam. From morning to 
night, Islamic teachings always governs life. Banjar people must be Moeslem (Syarifuddin \& Amka, 1995). According to Daud (1997), it was almost certain that there were no adults or near-adults (teenagers) who could not pray and Banjar people were relatively obedient to their religion.

\section{Descriptive Analysis of Teenagers' Intellectual Intelligence}

By comparing each score obtained by the subject with the norm made by Raymod B. Cotrell, the descriptive data obtained on the level of adolescent intellectual intelligence were as followed:

Table 3.

Teenagers' Intellectual Intelligence Level

\begin{tabular}{|c|c|c|}
\hline Category & Amount & Percentage \\
\hline Geniuses > 170 & 1 & 0.14 \\
\hline $\begin{array}{l}\text { Very Superior } \\
140-169\end{array}$ & 0 & 0 \\
\hline $\begin{array}{l}\text { Superior } 120- \\
139\end{array}$ & 4 & 0.56 \\
\hline $\begin{array}{l}\text { High Average } \\
110-119\end{array}$ & 1 & 0.14 \\
\hline $\begin{array}{l}\text { Avarage } 90- \\
109\end{array}$ & 83 & 11.66 \\
\hline $\begin{array}{l}\text { Low Average } \\
80-89\end{array}$ & 192 & 26.97 \\
\hline $\begin{array}{l}\text { Borderline 30- } \\
69\end{array}$ & 222 & 31.18 \\
\hline $\begin{array}{l}\text { Mental } \\
\text { Defective <29 }\end{array}$ & 208 & 29.21 \\
\hline
\end{tabular}

From the data above, it could be seen that the level of intelligence in general adolescent in Banjarmasin city brackish obtained the category of mentally defective number 208 persons or $29.21 \%$ were then some 222 people classified as borderline or $31,18 \%$, for the category of low average 192 people or 26, 97\% and included average only 83 or $11.66 \%$ to the category of High Average was only 1 person or $0.14 \%$ as well as the genius category. From this explanation, in terms of intellectual intelligence in Banjarmasin adolescents, most of them were in the below average category. It could be concluded that adolescents in Banjarmasin city largely analytical skills in abstract situation was still below average (in the norm tests CFIT). The IQ value obtained from the CFIT test results was referred to as the Original IQ, because this value was a potential value that was innate in nature, and was more due to the age factor. IQ scores were not obtained as a result of experience or the learning process. This value might still change and develop in line with the age of a person. Therefore, the IQ scores obtained from this test were not directly related to academic achievement.

From this explanation, it could be seen from the intellectual intelligence of Banjarmasin youth that most of them were in the below average category. However, muscles and intelligence can evolve throughout the life of origin continue to be fostered and enhanced. That was in the right environment.

People could become increasingly intelligent. This was confirmed by research by neurophysiologists, including Marian Diamond at the University of California at Berkeley, in Linda Campbell (Campell \& et al, 2002) who had found that the brain could change physiologically as a result of learning and experience, for better or for worse. Throughout life, we could continue to develop mental abilities in a positive, honing, stimulating and interactive environment.

\section{Descriptive Analysis Level of Teenagers Internet Addiction}

By comparing each score obtained by the subject with the norms of the Internet Addiction Test proposed by Widyanto and McMurren (L. Widyanto \& M. Mc Murren, 2004), the descriptive data on the level of addiction were obtained as followed: 
Table 4

Teenagers's Internet Addiction Rate

\begin{tabular}{|c|c|c|}
\hline Category & Amount & Percentage \\
\hline $\begin{array}{ll}\text { Normal } & 0- \\
30 & \end{array}$ & 229 & 32.16 \\
\hline Low $31-49$ & 357 & 50,14 \\
\hline $\begin{array}{l}\text { Medium 50- } \\
79\end{array}$ & 124 & 17.42 \\
\hline $\begin{array}{l}\text { Weight } 80- \\
100\end{array}$ & 3 & 0.28 \\
\hline
\end{tabular}

From the data it could be seen that the rate of teenagers' addiction Banjarmasin city obtained a number of 357 persons or $50.14 \%$ were then some 229 people were classified as normal or $32,16 \%$, for the category of being only 124 people or $17.42 \%$ and the including the weight of only 3 people or $0.28 \%$. From this explanation, most of the teenagers in Banjarmasin were in the low category of internet addiction. It can be concluded that most of the adolescents in the city of Banjarmasin were able to use the internet according to their needs, to adapt online activities to other activities in their lives and they do not need the internet as a place to escape from problems.

\section{Inferential Analysis of Teenagers' \\ Religiosity Levels and Intellectual Intelligence with Teenagers' Addiction \\ Levels}

In this third test, the proposed hypothesis was:

\section{H1: Teenager's intellectual intelligence} and religiosity had significant affect to teenagers' internet addiction

H0: Teenager's intellectual intelligence and religiosity had no significant effect teenagers' internet addiction

Based on SPSS testing, the results of the analysis were as followed:
Table 5.

Coefficient of Teenagers' Level of Religiosity with Teenagers' Internet Addiction

\begin{tabular}{|c|c|c|c|c|c|c|}
\hline \multicolumn{2}{|c|}{ Model } & $\begin{array}{l}\text { Sum of } \\
\text { Squares }\end{array}$ & D f & $\begin{array}{l}\text { Mean } \\
\text { Square }\end{array}$ & $\mathrm{F}$ & Sig. \\
\hline \multirow[t]{3}{*}{1} & Regression & 10,849 & 2 & 5,424 & $\begin{array}{l}0.0 \\
29\end{array}$ & $\begin{array}{l}, 972 \\
\text { b }\end{array}$ \\
\hline & Residual & $\begin{array}{l}133026,90 \\
4\end{array}$ & 709 & $\begin{array}{l}187,6 \\
26\end{array}$ & & \\
\hline & Total & $\begin{array}{l}133037,75 \\
3\end{array}$ & 711 & & & \\
\hline
\end{tabular}

a. Dependent Variable: Addicted

b. Predictors: (Constant), Religiosity, Intelligence

Based on table 5, it could be showed that the Sig value was 0.972 (P> 0.05), therefore

the proposed hypothesis was rejected or in other words internet addiction was not significantly related to religiosity and intellectual intelligence of teenagers in Banjarmasin City.

The findings of this study were in line with research by Charlton (Charlton et al., 2012) which confirmed a negative correlation between internet use and religiosity. By taking a sample in Malaysia, Charlton also found that the higher the intensity of an individual in using the internet, the lower his religiosity.

Charlton, et al (2013) examined the correlation between the tendency of internet addiction and religiosity teenagers in their study and they found a negative correlation between the tendency of the level of internet addiction and religiosity in women.

However, in their study Charlton et al could not find a relationship between the level of religiosity and the tendency to internet addiction in their study. Likewise, with research conducted by Kosasih (2021) which showed that there was no influence between religiosity and the tendency of internet addiction for students.

The factor of religiosity was an important factor in a teenager in order to 
overcome deviant behavior, lack of understanding of religious values and norms was a fundamental factor in the occurrence of deviant behavior. Understanding of religious teachings had a function as a means of controlling human attitudes and behavior so that they remain in line with prevailing cultural values. Religious moral teachings were used as the main guide for its adherents to control attitudes.

However, religiosity in research done (Reflection \& Ciftci, 2017) showed that there was no significant association between the use of the Internet and religious belief. (Almenayes, 2015) also examined the relationship between religiosity and addiction to social media in his study found that religiosity was an important predictor in the variable of social media addiction, the results of the study showed that social media addiction has three factors, and religiosity from the results of linear regression calculations showed that only two addiction factors had a significant relationship with religiosity.

$$
\text { Armfield \& Holbert }
$$

investigated the correlation between religiosity and internet use. it was found that religiosity was a relatively weak predictor of internet use compared to variables such as age, income, and education. Short et al (2015) conducted a study about the correlation between religiosity and the use of Internet devoted to pornography in their studies and they found a negative correlation between the frequency of use of the Internet devoted to pornography and piety. In situations where individuals adhere to their religious beliefs and spiritual values, the rate of Internet use devoted to pornography was close to zero.

Internet use was problematic, in this case, internet addiction was considered a multidimensional syndrome consisting of behavioral and cognitive aspects that can affect social, professional and academic life (Caplan, 2005).

\section{Conclusion}

Based on the results of the analysis and discussion on the influence of teenagers' religiosity, adolescent intellectual intelligence with adolescent internet addiction in Banjarmasin City, it was known that the significance value of adolescent religiosity and intellectual intelligence on internet addiction through a significance value of 0.972 where $p>0.05$, which can be concluded that the hypothesis of the proposal was rejected, so that there was no influence of teenagers' religiosity and intellectual intelligence on internet addiction in Banjarmasin City.

Based on the research results and conclusions obtained during the study, the researchers hoped that this study will be useful for further research and it is recommended to find out other variables besides religiosity and intellectual intelligence. As Internet content, parental upbringing, self-control and so forth which were considered to affect the tendency of Internet addiction disorder and to pay attention to cultural factors. The study should also discuss the implementation of the concept of religion and to explain the various dimensions. It will take some pretesting and perhaps a focus group to be able to tap into what religion means to individuals in their daily lives.

\section{References}

Almenayes, J. J. (2015). Empirical Analysis of Religiosity As Predictor of Social Media Addiction. Journal of Arts and Humanities, 4(10), 44-52.

Ariyanto, A. (2017). Hubungan antara Kontrol Diri dengan Kecanduan Internet pada Remaja di Surakarta. Universitas Muhammadiyah Surakarta. Armfield, G. G., \& Holbert, R. L. (2003). The Relationship Between Religiosity and Internet Use. Journal of Media and Religion, 2(3), 129-144. 
Basri, A. S. H. (2014). Kecenderungan Internet Addiction Disorder Mahasiswa Fakultas Dakwah Dan Komunikasi Ditinjau dari Religiositas. Jurnal Dakwah, XV(2), 407-432.

Campell, L., \& dkk. (2002). Multiple Intelegences: Metode Terbaru Melesatkan Kecerdasan. Insani Press.

Caplan, S. E. (2005). A Social Skill Account of Problematic Internet Use. Journal of communication, 55(4), 721-736.

Charlton, J. P., Soh, P. C., \& dkk. (2012). Religiosity, adolescent internet usage motives and addiction: An Exploration. Information, Communication, \& Society, 16(10), 67-89.

Daud, A. (1997). Islam dan Masyarakat Banjar; Deskrispi dan Analisa Kebudayaan Banjar. RajaGrafindo Persada.

Ekasari, P., \& Dharmawan, A. H. (2012). Dampak sosial-ekonomi masuknya pengaruh internet dalam kehidupan remaja di pedesaan. Departemen Sains Komunikasi dan Pengembangan Masyarakat, Fakultas Ekologi Manusia, IPB.

Ekşi, H., \& Çiftçi, M. (2017). Predicting High School Students' Problematic Internet Use in Terms of Religious Beliefs and Moral Maturity. Addicta: The Turkish Journal on Addictions, 4(2), 193-206.

Glock, C. Y., \& Stark, R. (1994). Religion and Society in Tension. Rand McNally Company.

Hurlock, Elizabeth. H. (2000). Psikologi Perkembanagn Suatu Pendekatan Sepanjang Rentang Kehidupan (V). Erlangga.

Jalaluddin. (2008). Psikologi Agama. Jakarta: PT RajaGrafindo Persada. Raja Grafindo.

Koc, M. (2011). Internet Addiction and Psychopatology. , 10(1),143-148. The
Turkish Online Journal of Educational Technology, 10(1), 143-148.

Kosasih, A. V. N. A. (2021). Pengaruh Leisure Boredom dan Religiusitas Terhadap Kecenderungan Adiksi Internet Pada Mahasiswa UIN Sunan Gunung Djati Bandung [Skripsi]. UIN Sunan Gunung Djati.

Kumara, A. (1989). Studi Validitas dan Reliabilitas Culture Fair Intelegence Test Skala 3 sebagai Alat Ukur Intelegensi pada Para Mahasiswa.

Kurniawati, A. (2017). Pengaruh Kontrol Diri Terhadap Kecanduan Internet pada Remaja. Universitas Airlangga.

Kurniawati, J., \& Baroroh, S. (2016). Literasi Media Digital Mahasiswa Universitas Muhammadiyah Bengkulu. Komunikator, 8(2), 51-66.

L. Widyanto \& M. Mc Murren. (2004). The Psychometric Properties of The Internet Addiction Test. Cyber Psychology \& Behaviour, 7(4), 445453.

Muna, R. F., \& Tri Puji, A. (2014). Hubungan antara Kontrol Diri dengan kecenderungan Kecanduan Media Sosial pada Remaja Akhir. Jurnal Empati, 3(4).

Nahak, L. M., Berek, P. A., Riwoerohi, E. D. F., \& Fouk, M. F. W. (2019). Hubungan Antara Penggunaan Gadhget dengan Kecerdasan (Intelektual, Emosional, Spiritual, dan Sosial) Anak Usia Sekolah di SDK St Theresia Atambua II. Jurnal Sahabat Keperawatan, 1(02), 16-25.

Prasojo, R. A., Maharani, D. A., \& Hasanuddin, M. O. (2018). Mengujikan Internet Addiction Test (IAT) ke Responden Indonesia.

Putri, Y. S. (2016). Emosional, Dan Lingkungan Kerja Terhadap. Jurnal 
Studi Manajemen \& Organisasi, 13(13), 88-97.

Saniatuzzulfa, R., \& Wijiyanti, A. N. (2019).

Smartphone Addiction ditinjau dari

Subjective Well Being, Kecemasan

Sosial, dan Materalisme Pada

Mahasiswa. Psycho Idea, 17(2), 145153.

Short, M. B., Kasper, T. E., \& Wetterneck, C.

T. (2015). The Relationship Between

Religiosity and Internet Pornography Use. Journal of Religion and Health, 54(2), 571-583.

Suhardin, S., \& Hayadin, H. (2017). Pengaruh Layanan Pendidikan Agama di Sekolah Terhadap Religiusitas Siswa: Studi Expost Facto di Medan. Edukasi, 15(1), 294348.

Syarifuddin \& Amka. (1995). Pembidaan Budaya dalam Lingkungan Keluarga Daerah Kalimantan Selatan. Bagian Proyek Pengkajian dan Pembinaan Nilai-Nilai Budaya Kalimantan Selatan.

Young, K. (2016). Internet Addiction Test (IAT). Stoelting.

Young, K. S. (1996). Internet Addiction Disorder: The Emergence of New Clinical Disorder. Paper presented at the 104th annual meeting of the American Psychology Association. 